\title{
The Determination of the Antibacterial Activities of Rose, Thyme, Centaury and Ozone Oils Against Some Pathogenic Microorganisms
}

\author{
Ozon, Kantaron, Kekik ve Gül Yağlarının Bazı Patojenik Mikroorganizmalara Karșı \\ Antimikrobiyal Aktivitelerinin Belirlenmesi
}

\author{
Çiğdem Eda Balkan', Murat Karameșe ${ }^{2}$, Demet Çelebi³, Sabiha Aydoğdu', Yalçın Dicle ${ }^{4}$, Zeki Çalık ${ }^{2}$ \\ ${ }^{1}$ Atatürk University, Medical Faculty, Department of Microbiology, Erzurum, Turkey; ${ }^{2}$ Kafkas University, Medical Faculty, Department \\ of Microbiology, Kars, Turkey; ${ }^{3}$ Atatürk University, Veterinary Faculty, Department of Microbiology, Erzurum, Turkey; ${ }^{4}$ Muş Alparslan \\ University, School of Health, Department of Nursing, Muş, Turkey
}

\begin{abstract}
AIM: The increase in antibiotic-resistant bacteria has dramatically revived the interest in plant products as alternative antimicrobial agents to prevent the efficiency of pathogenic microorganisms. Our aim in this study is to show the antimicrobial activities of commercially obtained thyme, rose, centaury and ozone oils against the clinically important bacteria and yeasts.

METHODS: The antimicrobial activity of the thyme, rose, ozone and centaury oils were tested against Escherichia coli, Proteus vulgaris, Proteus mirabilis, Stenotrophomonas maltophilia, Enterococcus spp., Acinetobacter baumannii, Streptococcus spp., Citrobacter freundii, Staphylococcus aureus and Candida albicans strains. Disc diffusion method (Kirby-Bauer) was used to show the antimicrobial activity by measuring the zone diameters.
\end{abstract}

RESULTS: Most bacteria including Stenotrophomonas maltophilia (which is only sensitive to a few antibiotics) are found sensitive to the thyme oil. Gram positive bacteria and yeasts found more resistant than the Gram negative bacteria to the thyme oil. Escherichia coli and Staphylococcus aureus found sensitive to the rose oil. The anti-microbial activities of some herbal oils and ozone oil and rose oil were tried to be shown.

CONCLUSION: The thyme oil has a stronger antimicrobial activity than the rose, ozone and centaury oils. Herbal essential oils, especially thyme oil, are candidates to be alternatives in medical applications due to their anti-microbial effects.

Key words: bacteria; antimicrobial activity; disc diffusion method; herbal oils

Yard. Doç. Dr. Murat Karameşe, Kafkas University, Medical Faculty, Department of Microbiology, 36100 Kars, Turkey, Tel. 05548638853 Email.murat_karamese@hotmail.com

Gelis Taribi: 21.03.2015 • Kabul Tarihi: 27.05.2015

\section{ÖZET}

AMAÇ: Antibiyotiklere dirençli bakterilerin sayısındaki artıș, tedavi basamağında alternatif bitkisel ürünlerin kullanılmasına olan ilginin dramatik bir șekilde artıșına da sebep olmuștur. Bu çalıșmadaki amacımız, ticari olarak elde ettiğimiz ozon, gül, kantaron ve kekik yağlarının klinik olarak önemli bakteri ve mantarlara karșı olan antimikrobiyal etkilerinin gösterilmesidir.

YÖNTEM: Ozon, gül, kantaron ve kekik yağlarının Escherichia coli, Proteusvulgaris, Proteusmirabilis, Stenotrophomonas maltophilia, Enterococcus spp., Acinetobacter baumannii, Streptococcus spp., Citrobacter freundii, Staphylococcus aureus ve Candida albicans isimli mikroorganizmalara karșı antimikrobiyal aktiviteleri test edilmiștir; Disk difüzyon metodu (Kirby-Bauer) kullanılmıș ve olușan zon çapları ölçülerek anti-mikrobiyal etki ortaya konulmuștur.

BULGULAR: Sadece birkaç antibiyotiğe karșı duyarlı olan Stenotrophomonas maltophilia bașta olmak üzere birçok bakteri, kekik yağına karșı duyarlı olarak tespit edilmiștir. Gram pozitif bakterilerin ve Kandida sușlarının kekik yağına, Gram negatif bakterilerden daha dirençli oldukları görülmüștür. Bunun yanı sıra Escherichia coli ve Staphylococcus aureus sușlarının ise gül yağına karșı duyarlı oldukları tespit edilmiștir. Bazı herbal yağların ve ozon yağının muhtemel antimikrobiyal etkileri bu çalıșma ile ortaya koyulmaya çalıșılmıștır.

SONUÇ: Kekik yağının antimikrobiyal etkinliği ozon, gül ve kantaron yağından oldukça yüksek düzeyde tespit edilmiștir. Sonuç olarak bașta kekik yağı olmak üzere bitkisel uçucu yağlar, antimikrobiyal aktivitelerinden dolayı tıbbi ilaç uygulamalarına iyi bir alternatif olabilme potansiyeli tașımaktadır.

Anahtar kelimeler: bakteriler; anti-mikrobiyal aktivite; disk difüzyon testi; bitkisel yağlar 


\section{Introduction}

A big percentage of the population uses herbal products for preventative and therapeutic purposes. The increase in antibiotic-resistant bacteria has dramatically revived the interest in plant products as alternative antimicrobial agents to prevent the efficiency of pathogenic microorganisms. A major group of plant antimicrobial compounds is represented by essential oils, which are complex mixtures of volatile secondary metabolites. They are mostly used in the food industry because of their preservative activity against food-borne pathogens, thanks to their antimicrobial, antibacterial, and antifungal properties ${ }^{1,2}$.

Plant essential oils are generally isolated from nonwoody plant material by distillation methods, usually by evaporation or hydro-distillation. These oils contains variable mixtures such as terpenoids, specifically monoterpenes [C10] and sesquiterpenes [C15] although diterpenes [C20] is also present, and a variety of low molecular weight aliphatic hydrocarbons acids (linear, ramified, saturated and unsaturated), alcohols, aldehydes, acyclic esters or lactones, nitrogen- and sulphur-containing compounds and homologues of phenyl-propanoids in their ingredients. Terpenes are one of the important chemicals responsible for the medicinal, culinary and fragrant uses of aromatic and medicinal plants ${ }^{3}$.

Hypericumperforatum (centaury oil) is one of the beststudied medicinal plants all over the world and its chemical ingredients are well-characterized. The phytopharmaceuticals based on standardized extracts have been approved against mild to moderate depression and for the short-term treatment of symptoms in mild depressive disorders. Moreover, Hypericumperforatum can be effective in the treatment of somatoform disorders, anxiety disorder, sleep disorders, obsessive compulsive disorder and seasonal affective disorder ${ }^{4-7}$.

In recent years, interest in natural products has increased, and medicinal plants have been investigated for various biological activities and therapeutic potentials ${ }^{8}$. Oil of thyme is derived from thyme, also known as Thymus vulgaris. Thyme also has a number of medicinal properties, which is due to the herb's essential oils. The health benefits of thyme essential oil can be attributed to its properties as an antispasmodic, antirheumatic, antiseptic, bactericidal, cardiac, carminative, cicatrisant, diuretic, expectorant, hypertensive, insecticide, stimulant and tonic substance. Oil of Thymus vulgaris has been shown to exhibit antimicrobial activities against pathogenic microorganisms $s^{9,10}$.

Rosa damascena is popular in the world for its perfume ${ }^{11}$. This plant has several therapeutic effects such as treatment of menstrual bleeding, digestive problems, antiinflammatory, the analgesic, anticonvulsant, antitussive, and bronchodilatory effects ${ }^{12,13}$. Addition to these activities, rose oil (Rosa damascena), has an antimicrobial performance against some microorganisms ${ }^{14}$.

And the final oil which is used in this study is ozone oil. The biocidal activity of ozone reveals by a combination of its high oxidation potential, reacting with organicmaterial up to 3,000 times faster than chlorine, and its ability to diffuse through biological cell membranes ${ }^{15}$.

Our aim in this study is to show the antimicrobial activities of these herbal oils and compare the possible antimicrobial effects.

\section{Method}

The essential oils of thymus, rose, centaury and ozone were screened for antimicrobial activity using an agar diffusion technique (Kirby-Bauer Disc Diffusion Method) against the following pathogenic microorganisms; Escherichiacoli, Proteus vulgaris, Proteus mirabilis, Stenotrophomonasmaltophilia, Enterococcus faecalis, Acinetobacter baumannii, Streptococcus spp, Citrobacterfreundii, Staphylococcusaureus and Candidaalbicans.

At first, Escherichia coli (ATCC 25922), Staphylococcus aureus (ATCC 25923) and Candida albicans (ATCC 10231) were standard bacterial strains which provided from American Type Culture Collection (ATCC). Then, other microorganisms were isolated from the samples by using Automatic Bacteria Identification Machine (VITEK-2 Compact System, BioMerieux, France). Then identified bacteria were cultured with stock medium and stored at $-80^{\circ} \mathrm{C}$ till the experiment day.

The fresh passages were performed before the study and for the inoculum, colonies were selected from 18-24 h old plates. Turbidity was visually adjusted to that of a $0.5 \mathrm{McF}$ arland turbidity standard $(1.5 \times 10$ $\sim \mathrm{CFU} / \mathrm{ml}$ ) using sterile Mueller-Hinton broth. Sterile filter paper disks were prepared to a diameter of $6.35 \mathrm{~mm}$ and sterilized in a Pasteur-oven, (at 170 $\sim$ for 2 hour). On the other hand, essential oils and extracts were sterilized by passing through $0.22 \mathrm{~mm}$ pore-size membrane filters and then $20 \mathrm{HI}(0.02 \mathrm{ml})$ 
of the solution of essential oils was pipetted $(0.1 \mathrm{ml})$ into the center of each disk to achieve the desired potency. By the way, the herbal oils were commercially provided. The manufacturer extraction protocol is seen in the following sentence: "It is extracted from the fresh or partly dried flowering tops and leaves of the plant by water or steam distillation and the yield is $0.7-1.0 \%$ ". Also, the concentration of herbal oils were $100 \%$.

To compare the antimicrobial activity of these oils, we used some standard commercial antibiotics onto these microorganisms such as Ampicillin 25 $\mu \mathrm{g}$ (Oxoid, USA), Imipenem 10ug (Oxoid, USA), Gentamycin30ug

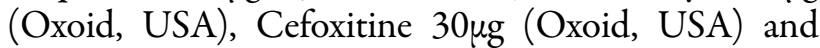

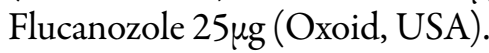

Disks were air-dried in a contamination free environment. E.coli, P.vulgaris, P.mirabilis, S.maltophilia, E. faecalis, A.baumannii, Streptococcus spp, C.freundii, S.aureus and C.albicans were swabbed onto the surface of Mueller-Hinton agar plates by rotating the plates approximately with a sterile cotton swab. Inoculated plates were allowed to stand for at least 3 minutes before applying antimicrobial disks.Disks were not placed closer to each other than $24 \mathrm{~mm}$, measured from center to center. Plates were incubated at $37^{\circ} \mathrm{C}$ for $18-24 \mathrm{~h}$.
After overnight incubation, the diameter of the zone of inhibition around each disk was measured in $\mathrm{mm}$. The measurement was performed by a scale and evaluated by 2 different microbiologists. The obtained data were compared with the standard antibiotics zone diameters which were evaluated according to The Clinical and Laboratory Standards Institute (CLSI) criteria.

\section{Results}

Antimicrobial activities of rose, thyme, centaury and ozone oils were determined by agar diffusion against nine pathogenic bacteria and yeasts. On the other hand, standard commercial antibiotics were also applied to the same pathogens. Rose oil was only effective on E.coli and S.aureus while centaury oil and ozonized oil have no antimicrobial effects of all microorganisms. However, rose oil zone diameters were quite low when compared with standard commercial antibiotics. Additionally, the thyme oil has a stronger antimicrobial activity than other oils, when the data were evaluated. It has no antimicrobial effects only on A.baumannii and Candida albicans. The biggest effect of thyme oil was detected on Citrobacter and Streptococcus strains. The zone diameters were 24 and $21 \mathrm{~mm}$ respectively. On the other hand, thyme oil had higher zone diameters from Gentamycin and nearly same diameters for cefoxitin (Table 1).

Table 1. The data about the antimicrobial activity of oils

\begin{tabular}{|c|c|c|c|c|c|c|c|c|c|c|}
\hline \multirow[b]{2}{*}{ Oils } & \multicolumn{10}{|c|}{ Bacteria } \\
\hline & E.coli & $\begin{array}{l}\text { Proteus } \\
\text { vulgaris }\end{array}$ & $\begin{array}{l}\text { Proteus } \\
\text { mirabilis }\end{array}$ & S.maltophilia & E.faecalis & $\begin{array}{c}\text { Acinetobacter } \\
\text { baumannii }\end{array}$ & $\begin{array}{c}\text { Streptococcus } \\
\text { spp. }\end{array}$ & $\begin{array}{l}\text { Citrobacter } \\
\text { freundii }\end{array}$ & S.aureus & $\begin{array}{l}\text { Candida } \\
\text { albicans }\end{array}$ \\
\hline Rose & $\begin{array}{l}\text { Zone } \\
\geq 5 \mathrm{~mm}\end{array}$ & $\begin{array}{c}\text { No } \\
\text { zone }\end{array}$ & $\begin{array}{c}\text { No } \\
\text { zone }\end{array}$ & $\begin{array}{c}\text { No } \\
\text { zone }\end{array}$ & $\begin{array}{c}\text { No } \\
\text { zone }\end{array}$ & $\begin{array}{l}\text { No } \\
\text { zone }\end{array}$ & $\begin{array}{c}\text { No } \\
\text { zone }\end{array}$ & $\begin{array}{l}\text { No } \\
\text { zone }\end{array}$ & $\begin{array}{c}\text { Zone } \\
\geq 3 \mathrm{~mm}\end{array}$ & $\begin{array}{c}\text { No } \\
\text { zone }\end{array}$ \\
\hline Thyme & $\begin{array}{c}\text { Zone } \\
\geq 19 \mathrm{~mm}\end{array}$ & $\begin{array}{c}\text { Zone } \\
\geq 17 \mathrm{~mm}\end{array}$ & $\begin{array}{c}\text { Zone } \\
\geq 17 \mathrm{~mm}\end{array}$ & $\begin{array}{c}\text { Zone } \\
\geq 20 \mathrm{~mm}\end{array}$ & $\begin{array}{c}\text { Zone } \\
\geq 19 \mathrm{~mm}\end{array}$ & $\begin{array}{c}\text { No } \\
\text { zone }\end{array}$ & $\begin{array}{c}\text { Zone } \\
\geq 21 \mathrm{~mm}\end{array}$ & $\begin{array}{c}\text { Zone } \\
\geq 24 \mathrm{~mm}\end{array}$ & $\begin{array}{c}\text { Zone } \\
\geq 17 \mathrm{~mm}\end{array}$ & $\begin{array}{c}\text { No } \\
\text { zone }\end{array}$ \\
\hline Centaury & $\begin{array}{c}\text { No } \\
\text { zone }\end{array}$ & $\begin{array}{c}\text { No } \\
\text { zone }\end{array}$ & $\begin{array}{c}\text { No } \\
\text { zone }\end{array}$ & $\begin{array}{c}\text { No } \\
\text { zone }\end{array}$ & $\begin{array}{c}\text { No } \\
\text { zone }\end{array}$ & $\begin{array}{c}\text { No } \\
\text { zone }\end{array}$ & $\begin{array}{c}\text { No } \\
\text { zone }\end{array}$ & $\begin{array}{c}\text { No } \\
\text { zone }\end{array}$ & $\begin{array}{c}\text { No } \\
\text { zone }\end{array}$ & $\begin{array}{c}\text { No } \\
\text { zone }\end{array}$ \\
\hline Ozone & $\begin{array}{c}\text { No } \\
\text { zone }\end{array}$ & $\begin{array}{c}\text { No } \\
\text { zone }\end{array}$ & $\begin{array}{c}\text { No } \\
\text { zone }\end{array}$ & $\begin{array}{c}\text { No } \\
\text { zone }\end{array}$ & $\begin{array}{c}\text { No } \\
\text { zone }\end{array}$ & $\begin{array}{l}\text { No } \\
\text { zone }\end{array}$ & $\begin{array}{c}\text { No } \\
\text { zone }\end{array}$ & $\begin{array}{c}\text { No } \\
\text { zone }\end{array}$ & $\begin{array}{c}\text { No } \\
\text { zone }\end{array}$ & $\begin{array}{c}\text { No } \\
\text { zone }\end{array}$ \\
\hline Ampicilin & $\geq 28 \mathrm{~mm}$ & $\geq 21 \mathrm{~mm}$ & $\geq 20 \mathrm{~mm}$ & $\begin{array}{c}\text { Not } \\
\text { applied }\end{array}$ & $\geq 18 \mathrm{~mm}$ & $\begin{array}{c}\text { Not } \\
\text { applied }\end{array}$ & $\geq 24 \mathrm{~mm}$ & $\geq 26 \mathrm{~mm}$ & $\geq 33 \mathrm{~mm}$ & $\begin{array}{c}\text { Not } \\
\text { applied }\end{array}$ \\
\hline Imipenem & $\geq 23 \mathrm{~mm}$ & $\geq 21 \mathrm{~mm}$ & $\geq 19 \mathrm{~mm}$ & $\begin{array}{c}\text { Not } \\
\text { applied }\end{array}$ & $\begin{array}{c}\text { Not } \\
\text { applied }\end{array}$ & $\geq 16 \mathrm{~mm}$ & $\geq 22 \mathrm{~mm}$ & $\geq 20 \mathrm{~mm}$ & $\geq 18 \mathrm{~mm}$ & $\begin{array}{c}\text { Not } \\
\text { applied }\end{array}$ \\
\hline Gentamycin & $\geq 18 \mathrm{~mm}$ & $\geq 17 \mathrm{~mm}$ & $\geq 15 \mathrm{~mm}$ & $\begin{array}{c}\text { Not } \\
\text { applied }\end{array}$ & $\begin{array}{c}\text { Not } \\
\text { applied }\end{array}$ & $\geq 14 \mathrm{~mm}$ & $\begin{array}{c}\text { Not } \\
\text { applied }\end{array}$ & $\geq 19 \mathrm{~mm}$ & $\geq 15 \mathrm{~mm}$ & $\begin{array}{c}\text { Not } \\
\text { applied }\end{array}$ \\
\hline Cefoxitin & $\geq 19 \mathrm{~mm}$ & $\geq 20 \mathrm{~mm}$ & $\geq 22 \mathrm{~mm}$ & $\begin{array}{c}\text { Not } \\
\text { applied }\end{array}$ & $\begin{array}{c}\text { Not } \\
\text { applied }\end{array}$ & $\begin{array}{c}\text { Not } \\
\text { applied }\end{array}$ & $\begin{array}{c}\text { Not } \\
\text { applied }\end{array}$ & $\geq 23 \mathrm{~mm}$ & $\geq 25 \mathrm{~mm}$ & $\begin{array}{c}\text { Not } \\
\text { applied }\end{array}$ \\
\hline Flucanozole & $\begin{array}{c}\text { Not } \\
\text { applied }\end{array}$ & $\begin{array}{c}\text { Not } \\
\text { applied }\end{array}$ & $\begin{array}{c}\text { Not } \\
\text { applied }\end{array}$ & $\begin{array}{c}\text { Not } \\
\text { applied }\end{array}$ & $\begin{array}{c}\text { Not } \\
\text { applied }\end{array}$ & $\begin{array}{c}\text { Not } \\
\text { applied }\end{array}$ & $\begin{array}{c}\text { Not } \\
\text { applied }\end{array}$ & $\begin{array}{c}\text { Not } \\
\text { applied }\end{array}$ & $\begin{array}{c}\text { Not } \\
\text { applied }\end{array}$ & $\geq 18 \mathrm{~mm}$ \\
\hline
\end{tabular}




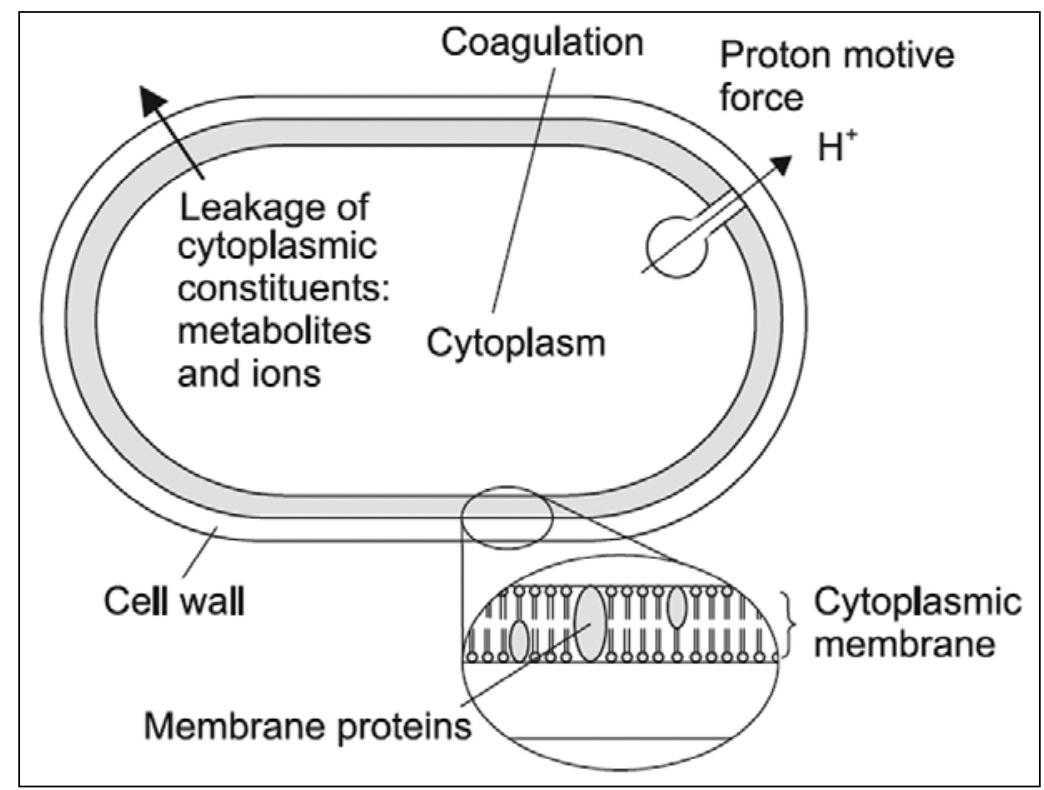

Figure 1. Essential oils components effects: degradation of the cell wall, damage tocytoplasmic membrane, damage to membrane proteins, leakage of cell contents, coagulation of cytoplasm, and depletion of the proton motive force ${ }^{25}$.

Some antimicrobial agents which are routinely used in Microbiology Laboratories were used for this study to compare the antimicrobial activities. Ampicillin was the antimicrobial agent which had the largest diameter zones. Also imipenem had larger zones after ampicillin. At that point, it was seen that thyme oil had close diameter zones with these two important antibiotics. In addition, thyme oil was effective to all bacteria except Acinetobacter baumannii.

\section{Discussion}

One of the alternative strategies to eliminate antibiotic-resistant bacteria is the use of natural antimicrobial substances such as plant essential oils and their components ${ }^{16}$. On the other hand comparing the antibacterial effect of these plants is important for choosing the most appropriate ones. In this study, the effects of rose, thyme, centaury and ozone oils were determined and compared against 9 different pathogenic and resistant microorganisms.

The results of the present study indicate that the thyme oil has important antimicrobial effects on some pathogenic microorganisms. In our country, thyme was traditionally used to treat medical symptoms such as coughing, upper respiratory congestion, gastritis, bronchitis, spasm, sprains, stomach cramps, dysmenorrhea, dyspepsia, and urinary tract infection (Figure 1$)^{17}$. Because of the ingredient of Thymus vulgaris (Thymol 10-64\%, Carvacrol $2-11 \%$, g-Terpinene 2-31\%, p-Cymene $10-56 \%)$, it may has a strong antimicrobial activity as seen in this study ${ }^{18,19}$. It seems reasonable that mechanism of action of thyme oil would therefore be similar to other phenolic; this is generally considered to be the disturbance of the cytoplasmic membrane, disrupting the proton motive force (PMF), electron flow, active transport and coagulation of cell contents ${ }^{20}$.

Other herbal oils were also evaluated and it was seen that rose oil has an antimicrobial activity. However, this activity was limited with 2 microorganisms. In the current literature, antibacterial effect of major components of rose oil (citronellal, geraniol and nerol) was reported previously ${ }^{21-24}$. Rose oil is a volatile oil obtained by distillation of the fresh flowers of R.damascena. The chief producing countries are Bulgaria, Turkey and Morocco $^{11}$. The identified compounds from rose oils were; $\beta$-citronellal (14.5-47.5\%), nonadecane (10.5$40.5 \%)$, geraniol (5.5-18\%), and nerol and kaempferol were the major components of the oil ${ }^{25}$. The in vitro antibacterial activities of essential oil from R.damascene were also shown by disk diffusion testing against E.coli, S.aureus and P.aeruginosa. R.damascene showed antimicrobial activity against $S$.aureus in some studies ${ }^{21}$. Our results suggest that essential oils have potential use as 
antimicrobials especially thyme and rose oils. Essential oils and main components of some of these oils, such as carvacrol, citronellal, geraniol, and nerol have been previously reported to have antibacterial effects ${ }^{26}$.

On the other hand, there were no antimicrobial effects for centaury and ozone oils .n this study. No zone diameters were detected for these 2 oils. However, there must be 2 reasons to explain this issue. First one; the bacteria used in this study were selected from the most resistant to the most antibiotics and Extended spectrum beta-lactamase (ESBL) positives. And the second reason is that the oil dose might be inadequate. So, new doses experiments should be performed to put out the real data about the antimicrobial activities of ozone and centaury oils.

In conclusion, our study showed that because of strong antibacterial effects of the thymus and rose oil (Table 1). These oils can be used in treatment process as an alternative application structures. The intensive use of antibiotics has often resulted in the development of resistant strains.As found in this study,plant essential oils may be an alternative treatment options and may be used for elimination of some bacteria.

\section{References}

1. Hyldgaard M, Mygind T, Meyer RL. Essential oils in food preservation: mode of action, synergies, and interactions with food matrix components. Front Microbiol 2012;3:12.

2. Cowan MM. Plant products as antimicrobial agents. Clin Microbiol Rev 1999;12:564-82.

3. Dorman HJ, Deans SG. Antimicrobial agents from plants: antibacterial activity of plant volatile oils. J Appl Microbiol 2000;88:308-16.

4. Chen XW, Serag ES, Sneed KB, et al. Clinical herbal interactions with conventional drugs: from molecules to maladies. Curr Mel Chem 2011;8:4836-50.

5. Can OD, Ozturk Y, Ozturk N, et al. Effects of treatment with St. John's wort on blood glucose levels and pain perceptions of streptozotocin diabetic rats. Fitoterapia 2011;82:576-84.

6. Kasper S, Caraci F, Forti B, et al. Efficacyand tolerability of Hypericum extract for the treatment of mild to moderate depression. Eur Neuropsychopharmacol 2010;20:747-65.

7. Gaster B, Holroyd J. St John's wort for depression: a systematic review. Arch Intern Med 2000;24;152-6.

8. Ahmad I, Beg AZ. Antimicrobial and phytochemical studies on 45 Indian medicinal plants against multi-drug resistant human pathogens. J Ethnopharcol 2001;74:113-23.

9. Giordani R, Regli P, Kaloustian J, et al. Antifungal effect of various essential oils against Candida albicans. Potentiation of antifungal action of amphotericin B by essential oil from Thymus vulgaris. Phytother Res 2004;18:990-5.
10. Pinto E, Pina-Vaz C, Salgueiro L, et al. Antifungal activity of the essential oil of Thymus pulegioides on Candida, Aspergillus and dermatophyte species. J Med Microbiol 2006;55:1367-70.

11. Loghmani-Khouzani H, Sabzi-Fini O, Safari J. Essential oil composition of Rosa damascena mill cultivated in central Iran. Scientia Iranica 2007;14:316-9.

12. Boskabady MH, Shirmohammadi B, Jandaghi P, et al. Possible mechanism (s) for relaxant effect of aqueous and macerated extracts from Nigella sativa on tracheal chains of guinea pig. BMC Pharmacol 2004;25:3.

13. Hajhashemi V, Ghannadi A, Hajiloo M. Analgesic and Antiinflammatory Effects of Rosa damascenaHydroalcoholic Extract and its Essential Oil in Animal Models. Iran J Pharm Res 2010;9:163-8.

14. Ulusoy S, Bosgelmez-Tinaz G, Secilmis-Canbay H. Tocopherol, carotene, phenolic contents and antibacterial properties of rose essential oil, hydrosol and absolute. Curr Microbiol 2009;59:554-8.

15. Kim JG, Yousef AE, Chism GW. Use of ozone toinactivate microorganism on lettuce. J Food Safety 1999;19:17-34.

16. Magi G, Marini E, Facinelli B. Antimicrobial activity of essential oils and carvacrol, and synergy of carvacrol and erythromycin, against clinical, erythromycin-resistant Group A Streptococci. Front Microbiol 2015;6:165.

17. Ozcan M, Chalchat J. Aroma profile of Thymus Vulgaris L. Growing wild in Turkey. Bulg J Plant Physiol 2004;30:68-73.

18. McGimpsey JA, Douglas MH, Van Klink JL, et al. Seasonal variation in essential oil yieldand composition from naturalized Thymus vulgaris L. in New Zealand. Flavour Fragr J 1994;9:34752.

19. Cosentino S, Tuberoso CI, Pisano B, et al. In vitro antimicrobial activity andchemical composition of Sardinian Thymus essential oils. Lett Appl Microbiol 1999;29:130-5.

20. Daferera DJ, Ziogas BN, Polissiou MG. GC-MS analysisof essential oils from some Greek aromatic plants and theirfungitoxicity on Penicilliumdigitatum. J Agric Food Chem 2000;48:2576-81.

21. Andogan BC, Baydar H, Kaya S, et al. Antimicrobial activity and chemical composition ofsome essential oils. Arch Pharm Res 2002;25:860-4.

22. Basim E, Basim H. Antibacterial activity of Rosa damascena essential oil. Fitoterapia 2003;74:394-6.

23. Achuthan $\mathrm{CR}$, Babu BH, Padikkala J. Antioxidant andhepatoprotective effects of Rosa damascena. Pharm Biol 2003;41:357-61.

24. Gochev V, Wlcek K, Buchbauer G, et al. Comparative evaluation of antimicrobial activity and composition of rose oils from various geographic origins, in particular Bulgarian rose oil. Nat Prod Commun 2008;3:1063-8.

25. Aydinli M, Tutas M. Production of rose absolute from rose concrete. Flavour Fragr J 2003;18:32-5.

26. Janssen AM, Sheffer JJ, Baerheim-Svendsen A. Antimicrobial activity of essential oils: A 19761986 literature review: Aspects of the test methods. Planta Med 1987;53:395-8. 